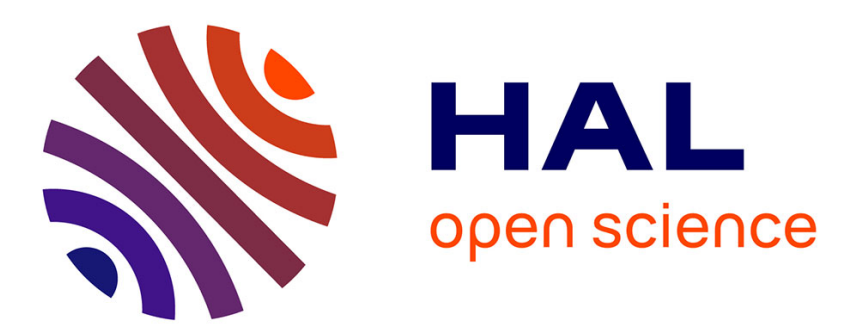

\title{
Heat production by bacterial magnetosomes exposed to an oscillating magnetic field
}

\author{
E. Alphandéry, S. P. Faure, Lydia Raison, Etienne Duguet, P. A. Howse, D.
}

A. Bazylinski

\section{- To cite this version:}

E. Alphandéry, S. P. Faure, Lydia Raison, Etienne Duguet, P. A. Howse, et al.. Heat production by bacterial magnetosomes exposed to an oscillating magnetic field. Journal of Physical Chemistry C, 2011, 15 (1), pp.18-22. 10.1021/jp104580t . hal-00559506

\section{HAL Id: hal-00559506 https://hal.science/hal-00559506}

Submitted on 26 Jun 2017

HAL is a multi-disciplinary open access archive for the deposit and dissemination of scientific research documents, whether they are published or not. The documents may come from teaching and research institutions in France or abroad, or from public or private research centers.
L'archive ouverte pluridisciplinaire HAL, est destinée au dépôt et à la diffusion de documents scientifiques de niveau recherche, publiés ou non, émanant des établissements d'enseignement et de recherche français ou étrangers, des laboratoires publics ou privés. 


\title{
Heat Production by Bacterial Magnetosomes Exposed to an Oscillating Magnetic Field
}

\author{
E. Alphandéry ${ }^{+}$, S. Faure"l, L. Raison*, E. Duguet", P. A. Howse ${ }^{\perp}$, D. A. Bazylinski ${ }^{\perp}$
}

${ }^{+}$Université Pierre et Marie-Curie, Institut de Minéralogie et de physique de la matière condensée (IMPMC), 140 rue de Lourmel, UMR 7590, CNRS, 75015, Paris, France.

"Nanobacterie, SARL, 36 boulevard Flandrin, 75016, Paris, France.

\begin{abstract}
*CNRS, Université de Bordeaux, ICMB, 87, avenue du Docteur Albert Schweitzer, F-33 608 PESSAC Cedex, France.

${ }^{\perp}$ University of Nevada at Las Vegas, School of life sciences, 4505 Maryland Parkway, Las Vegas, NV 89154-4004, USA.
\end{abstract}

\begin{abstract}
:
In this work, we examine the mechanisms of heat production by whole intact cells of magnetotactic bacteria, Magnetospirillum magneticum strain AMB-1, as well as by their extracted chains of magnetosomes or extracted individual magnetosomes when they are exposed to an oscillating magnetic field of frequency $108 \mathrm{kHz}$ and field amplitudes varied between $23 \mathrm{mT}$ and $88 \mathrm{mT}$. For intact bacterial cells that contain chains of magnetosomes, heat is generated through hysteresis losses yielding specific absorption rates $(\mathrm{SAR})$ of $110 \mathrm{~W} / \mathrm{g}_{\mathrm{Fe}}$ at $23 \mathrm{mT}$ and $860 \mathrm{~W} / \mathrm{g}_{\mathrm{Fe}}$ at $88 \mathrm{mT}$. When the chains of magnetosomes are extracted from the bacterial cells and exposed to the same magnetic field, the heatproducing mechanism includes an additional contribution, one that is due to their rotation in the magnetic field. This results in the production of higher SAR of $860 \mathrm{~W} / \mathrm{g}_{\mathrm{Fe}}$ at $23 \mathrm{mT}$ and $1240 \mathrm{~W} / \mathrm{g}_{\mathrm{Fe}}$ at $88 \mathrm{mT}$. Lower SAR values of $540 \mathrm{~W} / \mathrm{g}_{\mathrm{Fe}}$ at $23 \mathrm{mT}$ and $970 \mathrm{~W} / \mathrm{g}_{\mathrm{Fe}}$ at $88 \mathrm{mT}$ are obtained with the individual magnetosomes. This appears to be due to aggregation of the individual magnetosomes in the liquid, which prevents them from rotating as efficiently as the chains of magnetosomes.
\end{abstract}




\section{Introduction:}

Magnetotactic bacteria are a unique group of bacteria that biomineralize intracellular, membranebounded, nanometer-sized single-magnetic-domain crystals of the iron oxide magnetite $\left(\mathrm{Fe}_{3} \mathrm{O}_{4}\right)$, maghemite $\left(\gamma \mathrm{Fe}_{2} \mathrm{O}_{3}\right)$ and/or iron sulfide greigite $\left(\mathrm{FeS}_{4}\right)(1)$. These structures, called magnetosomes, are most often arranged as a chain within the cells. They are used by the bacteria to navigate in the direction of the Earth's magnetic field and help them to find optimal conditions for their growth and survival (1).

Magnetosomes have been shown to be useful in a number of scientific, commercial and health applications (2). Recently, great efforts have been devoted to synthesizing nanoparticles, which are able

to induce the production of heat when an oscillating magnetic field is applied to them (3). The aim of this effort is to improve the treatments of tumors by hyperthermia or thermoablation or to enable the release of drugs within a localized region of the body (3-9). Although rapid progresses have been made in this field, concerns have been raised regarding the toxicity induced by the presence of the nanoparticles in the body (10). In order to minimize the potential side effects of nanoparticle based clinical treatments, the nanoparticles need to be administered in a quantity as small as possible. For that, the latter have to generate a sufficiently large amount of heat (specific absorption rates SAR). This can be achieved by using nanoparticles with either a large volumes or a high magnetocrystalline anisotropy (11). The magnetosomes belong to the largest single domain ferrite nanoparticles, making them good candidates for the applications mentioned above. Although the magnetosomes have been shown to produce a large amount of heat when they are subjected to an oscillating magnetic field (11-13), this property has not been fully explained.

In this paper, we provide a detailed study of the mechanisms of heat production by magnetosomes biomineralized by the magnetotactic bacteria. The magnetosomes studied in this paper are iron oxide nanoparticles of mean sizes $40 \mathrm{~nm}$, which are oxidized in maghemite and are arranged in chains 
containing $\sim 6$ magnetosomes $(14,15)$. Since maghemite and magnetite have similar magnetic properties at room temperature, the fact that the magnetosomes are oxidized in maghemite does not change the conclusions drawn in this paper. We compare the heat-producing properties of three different types of magnetosome arrangements $(14,15)$. We examine the properties of intact cells that contain chains of magnetosomes and those of the magnetosomes that have been extracted from cells and are either arranged in chains or form individual nanocrystals. It is known that for large ferromagnetic nanoparticles, there are two main heat-producing mechanisms. The first one is due to the physical rotation of magnetic nanoparticles in a magnetic field and the second one is a result of hysteresis losses (16). In order to determine which one of these two mechanisms is responsible for heat production by the three different types of magnetosome arrangements mentioned above, we compare the heating rates of the samples in water, in which rotation of the cells and extracted magnetosomes is possible, with those in a gel, where the rotation is inhibited. In this way, the amount of heat generated by the rotation of the bacteria or extracted magnetosomes and that arising from hysteresis losses can be determined. In order to verify that the heat produced in the gel is due to hysteresis losses, we measure the hysteresis losses independently using magnetic measurements.

\section{Results and discussion:}

Figure 1(a) depicts a transmission electron micrograph (TEM) of cells of Magnetospirillum magneticum strain AMB-1 showing typical chains of magnetosomes (designated by blue arrows). The volume occupied by magnetosomes in a whole cell is rather small, typically $\sim 0.02 \%$ of the entire volume of the cell. A suspension containing intact whole cells of M. magneticum is subjected to an oscillating magnetic field of frequency $v=108 \mathrm{kHz}$ and field amplitude varied between $\mathrm{H}_{0}=23 \mathrm{mT}$ and $\mathrm{H}_{0}=88 \mathrm{mT}$. The heating rates of cells suspended in liquid and those fixed within a gel increase when the magnetic field increases from $23 \mathrm{mT}$ up to $88 \mathrm{mT}$ (Figures 1(b) and 1(c)). The areas of the minor 
hysteresis loops of the whole intact cells (Figure 1(d)) also increase when the magnetic field amplitude increases from $23 \mathrm{mT}$ up to $88 \mathrm{mT}$. Using the method of Hergt et al (10), we deduce from the areas of the minor hysteresis loops shown in Figure 1(d) that the hysteresis losses of the intact cells increase from $110 \mathrm{~W} / \mathrm{g}_{\mathrm{Fe}}$ at $23 \mathrm{mT}$ up to $810 \mathrm{~W} / \mathrm{g}_{\mathrm{Fe}}$ at $88 \mathrm{mT}$ (Figure $1(\mathrm{e})$ ). In order to determine if the rotation of the intact cells contributes to the observed increase in temperature, we estimate the SAR of the intact cells suspended in liquid. The SAR of the cell suspension is estimated at $22{ }^{0} \mathrm{C}$ from the slopes of the variation with time of the temperature, $\Delta \mathrm{T} / \delta \mathrm{t}$, using the formula (1) below (12):

$\mathrm{SAR}=\mathrm{C}_{\text {water }}\left(\frac{\Delta \mathrm{T}}{\delta \mathrm{t}}\right) \frac{1}{\mathrm{x}_{\mathrm{m}}}$

, where $\mathrm{C}_{\text {water }}$ is the specific heat capacity of water $\left(\mathrm{C}_{\text {water }}=4.184 \mathrm{~J} / \mathrm{g} . \mathrm{K}\right)$ and $\mathrm{x}_{\mathrm{m}}$ is weight of iron per $\mathrm{mL}$ of liquid (water). As shown in Figure 1(e), the SAR of the bacterial suspension increase from $110 \mathrm{~W} / \mathrm{g}_{\mathrm{Fe}}$ up to $860 \mathrm{~W} / \mathrm{g}_{\mathrm{Fe}}$ when the magnetic field amplitude is increased from $23 \mathrm{mT}$ up to $88 \mathrm{mT}$. These values of the SAR are similar to those measured from the areas of the minor hysteresis loops shown in Figure 1(e). Unexpectedly, the SAR determined for cells fixed in the agarose gel is significantly smaller than the areas of the minor hysteresis loops, which correspond to the hysteresis losses (Figure 1(e)). This could be due to poor diffusion of heat within the bacterial cells when they are contained in the agarose gel. From these results, we hypothesize that the rotation of the whole bacterial cells does not contribute to the production of heat. This hypothesis is supported by the fact that the magnetosomes occupy a small volume within the whole bacteria. This small volume induces insufficient rotation of the cells to generate heat. Furthermore, the absence of contribution of the rotation can be confirmed by estimating

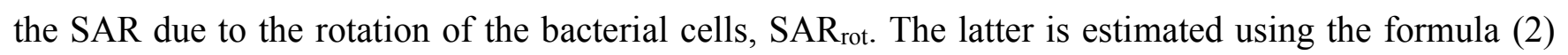
below $(16,17)$ : 
SAR ${ }_{\text {rot }}=\frac{1}{2} \frac{\left(M_{\mathrm{s}} \mathrm{H}_{\mathrm{o}} \mathrm{V}\right)^{2}}{\mathrm{~K}_{\mathrm{b}} \mathrm{T}} \frac{1}{\rho \mathrm{V}} \frac{1}{\tau_{\mathrm{b}}} \frac{\left(\omega \tau_{\mathrm{b}}\right)^{2}}{1+\left(\omega \tau_{\mathrm{b}}\right)^{2}}$

In (2), $\omega=2 \pi \mathrm{f}$, where $\mathrm{f}=108 \mathrm{kHz}$ is the frequency of the oscillating magnetic field, $\mathrm{M}_{\mathrm{s}}$ is the saturating magnetization of maghemite $\left(\mathrm{M}_{\mathrm{s}}=390 \mathrm{emu} / \mathrm{cm}^{3}\right), \mathrm{H}_{0}$ is the amplitude of the applied magnetic field (23 $\left.\mathrm{mT}<\mathrm{H}_{0}<88 \mathrm{mT}\right), \mathrm{V} \sim 2010^{-17} \mathrm{~cm}^{3}$ is the volume of a typical chain of magnetosomes $(13), \rho \sim 5 \mathrm{~g} / \mathrm{cm}^{3}$ is the specific weight of maghemite, $\mathrm{K}_{\mathrm{b}} \sim 1.3810^{-23} \mathrm{~J} / \mathrm{K}$ is the Boltzmann constant and $\tau_{\mathrm{b}} \sim 10$ seconds is the Brownian relaxation time of intact bacterial cell (18). Using these values, we find that SAR rot lies between $5.10^{-2} \mathrm{~W} / \mathrm{g}_{\mathrm{Fe}}$ and $7.10^{-1} \mathrm{~W} / \mathrm{g}_{\mathrm{Fe}}$ for $23 \mathrm{mT}<\mathrm{H}_{0}<88 \mathrm{mT}$. These values are much smaller than the measured hysteresis losses, which lie between $\sim 50 \mathrm{~W} / \mathrm{g}_{\mathrm{Fe}}$ at $23 \mathrm{mT}$ and $\sim 810 \mathrm{~W} / \mathrm{g}_{\mathrm{Fe}}$ at $88 \mathrm{mT}$ (Fig. 1(e)). Thus, the rotation of the whole bacterial cells does not appear to contribute to heat production. As indicated in the column bar plots of Figure 1(f), the SAR arises at $100 \%$ from hysteresis losses and becomes much more significant at a magnetic field amplitude of $88 \mathrm{mT}\left(\mathrm{SAR} \sim 860 \mathrm{~W} / \mathrm{g}_{\mathrm{Fe}}\right.$ ) than at a field amplitude of $23 \mathrm{mT}\left(\mathrm{SAR} \sim 110 \mathrm{~W} / \mathrm{g}_{\mathrm{Fe}}\right)$. This is due to the increase of hysteresis losses with increasing magnetic field amplitude as previously observed with chemically synthesized magnetite nanoparticles (16). The SAR per cycle of the whole cells in suspension, which is defined as the SAR divided by the frequency of the oscillating magnetic field, lies between $1 \mathrm{~J} / \mathrm{kg}_{\mathrm{Fe}}$ and $8 \mathrm{~J} / \mathrm{kg}_{\mathrm{Fe}}$. These values are higher than those observed with chemically synthesized nanoparticles, which typically lie between $0.001 \mathrm{~J} / \mathrm{kg}_{\mathrm{Fe}}$ and $1.2 \mathrm{~J} / \mathrm{kg}_{\mathrm{Fe}}$ for a wide range of nanoparticle sizes and compositions as well as for a large choice of magnetic field frequencies and amplitudes (16, 20-23). We conclude that the suspensions of whole magnetotactic bacteria produce a larger amount of heat than most of the chemically synthesized nanoparticles.

In order to increase even more the amount of heat produced by the magnetosomes, chains of magnetosomes are extracted from bacterial cells to presumably enhance their rotation in the magnetic 
field. To verify that the magnetosomes are actually extracted from the bacteria and remain in chains, we use electron microscopy. Figure 2(a) shows typical assemblies of chains of magnetosomes $(14,15)$, which are not aggregated in clumps but are sufficiently close one to another as chains to be interacting in several regions. Heating rates of the extracted chains of magnetosomes are shown in Figures 2(b) and 2(c) for the magnetic field amplitudes of $23 \mathrm{mT}$ and $88 \mathrm{mT}$ respectively. In the gel, they are similar to those determined for suspensions of intact whole bacterial cells while in solution, they are between 5 and 13 times larger than those of the whole cells (Figs. 1(b), 1(c), 2(b) and 2(c)). This suggests either that the extracted chains of magnetosomes produce larger hysteresis losses than intact bacteria cells or that their rotation contributes to the heat production or both. In order to discern which, if any, of these explanations is plausible, hysteresis losses of the extracted chains of magnetosomes are determined. Figure 2(d) shows the minor hysteresis loops of the chains at $23 \mathrm{mT}$ and $88 \mathrm{mT}$. Compared with the minor hysteresis loops obtained with the intact bacteria cells (Figure 1(d)), those for the extracted chains of magnetosomes decrease. This decrease is likely due to the interactions between the chains of magnetosomes (15). We conclude that the increase of the heating rate observed between the intact bacterial cells and the extracted chains of magnetosomes suspended in liquid is not due to an increase of hysteresis losses but to the rotation of the chains. The contribution of the rotation to the heating mechanism of the extracted chains of magnetosomes can be further confirmed by estimating the SAR of the extracted chains of magnetosomes suspended in liquid. We find that the latter increases from $\sim 860$ $\mathrm{W} / \mathrm{g}_{\mathrm{Fe}}$ at $23 \mathrm{mT}$ up to $\sim 1240 \mathrm{~W} / \mathrm{g}_{\mathrm{Fe}}$ at $88 \mathrm{mT}$. These values of the $\mathrm{SAR}$ are larger than the hysteresis losses deduced either from the SAR of the extracted chains in the gel (SAR $\sim 50 \mathrm{~W} / \mathrm{g}_{\mathrm{Fe}}$ at $23 \mathrm{mT}$ and $\mathrm{SAR} \sim 490 \mathrm{~W} / \mathrm{g}_{\mathrm{Fe}}$ at $88 \mathrm{mT}$ ) or from the areas of the minor hysteresis loops (SAR $\sim 110 \mathrm{~W} / \mathrm{g}_{\mathrm{Fe}}$ at $23 \mathrm{mT}$ and $\mathrm{SAR} \sim 490 \mathrm{~W} / \mathrm{g}_{\mathrm{Fe}}$ at $88 \mathrm{mT}$ ). In order to confirm the contribution of the rotation to the heating mechanism of the chains of magnetosomes, we measure SAR rot using (2), which factors in the Brownian relaxation time. This formula is applied below the saturating region where the SAR shows a strong 
dependence on the field amplitude (16). Since the saturation occurs above $36 \mathrm{mT}$ (Figure 2(e)), we only measure the SAR at $23 \mathrm{mT}$. Using a Brownian relaxation time $\tau_{\mathrm{B}} \sim 1.210^{-4} \mathrm{sec}(18)$, we find that $\mathrm{SAR}_{\text {rot }} \sim 3600 \mathrm{~W} / \mathrm{g}_{\mathrm{Fe}}$ at $23 \mathrm{mT}$, a value, which is larger than the $\mathrm{SAR}$ of $810 \mathrm{~W} / \mathrm{g}_{\mathrm{Fe}}$ deduced experimentally by measuring the difference between the SAR of magnetosome chains suspended in liquid $\left(860 \mathrm{~W} / \mathrm{g}_{\mathrm{Fe}}\right)$ and the SAR of the magnetosomes fixed in the gel $\left(50 \mathrm{~W} / \mathrm{g}_{\mathrm{Fe}}\right)$. The difference between the theoretical prediction and the experimental observation can be explained by the partial aggregation of the chains of magnetosomes. We conclude that the rotation contributes to the heating mechanism of the extracted chains of magnetosomes and that this contribution decreases from $90 \%$ of the SAR at $23 \mathrm{mT}$ down to $60 \%$ of the same SAR at $88 \mathrm{mT}$ (Figure 2(f)). This decrease could be explained by the stronger enhancement with increasing magnetic field amplitude of the hysteresis losses than of the SAR due to the rotation of the chains of magnetosomes in the magnetic field (16).

The third sample we test is a suspension of extracted magnetosomes whose membranes have been disrupted by a combination of heat and sodium deodecyl sulfate (SDS). Disruption of the magnetosome membrane results in a suspension of individual magnetosomes, which are not arranged in chains. Figure 3(a) shows a typical TEM micrograph of these magnetosomes and clearly shows that magnetosomes are not organized in chains. These nanocrystals interact and organize within compact assemblies of individual nanocrystals $(14,15,19)$, forming significantly more compact and aggregated assemblies than those observed in Figure 2(a). The heating rates of the liquid suspension containing these magnetosomes are shown in Figures 3(b) and 3(c) for the magnetic field amplitude of $23 \mathrm{mT}$ and 88 mT. They are lower than those observed for the extracted chains of magnetosomes suspended in liquid both at $23 \mathrm{mT}$ and $88 \mathrm{mT}$ (Figures 2(b), 2(c), 3(b) and 3(c)). The difference between the heating rates of the chains and individual magnetosomes can either be due to a difference in the contribution of the magnetosome rotation or hysteresis losses to the SAR. The hysteresis losses measured from the areas of 
the minor hysteresis loops (Figure 3(d)) or from the heating rates of the individual magnetosomes in the gel (Figures 3(b) and 3(c)) lie between $\sim 220 \mathrm{~W} / \mathrm{g}_{\mathrm{Fe}}$ and $\sim 430 \mathrm{~W} / \mathrm{g}_{\mathrm{Fe}}$ (Figure 3(e)), which are similar

values than the hysteresis losses estimated for the extracted chains of magnetosomes (Figure 2(e)). Therefore, the difference in SAR observed between the extracted chains of magnetosomes and the individual magnetosomes suspended in liquid must result from a difference in the contribution of the rotation to the heating mechanism. Equation 2 predicts that the SAR due to the rotation of the individual magnetosomes suspended in liquid should be the same as that deduced for the chains of magnetosomes, $\mathrm{SAR}_{\text {rot }} \sim 3600 \mathrm{~W} / \mathrm{g}_{\mathrm{Fe}}$ at $23 \mathrm{mT}$. Therefore the lower heating rate observed for the extracted individual magnetosomes is likely due to the fact that the latter are more prone to aggregation than the chains of magnetosomes. Aggregation of the individual magnetosomes is clearly evident using electron microscopy (Figure 3(a)) and can also be observed visually in liquid suspension. It prevents these magnetosomes from rotating as easily as the extracted chains of magnetosomes. As can be deduced from Figure 3(f), the contribution of the rotation to the heating mechanism lies between $44 \%$ and $60 \%$ of the total SAR. These percentages are lower than those obtained with the extracted chains of magnetosomes.

\section{Conclusion}

In this study, we have examined the heat-production by intact whole magnetotactic bacterial cells, extracted chains of magnetosomes and extracted individual magnetosomes exposed to an oscillating magnetic field. The SAR of each of these three magnetic samples is larger than that reported for smaller superparamagnetic nanoparticles. The predominant contribution to heat production by the intact bacterial cells appears to be hysteresis losses while physical rotation and hysteresis losses are both responsible for the generation of heat for the extracted chains of magnetosomes and individual magnetosomes. Magnetosomes organized in chains produce a greater amount of heat than individual 
magnetosomes (suspended in liquid) probably due to the latter's strong tendency to form aggregates in liquid.

\section{Experimental section:}

\section{IV.1 Preparation of the samples:}

Magnetospirillum magneticum strain AMB-1 magnetotactic bacteria are purchased from the ATCC (ATCC 700274). The bacteria are cultivated using the growth medium recommended by the ATCC, which contains in $1 \mathrm{~L}$ of distilled water, $5 \mathrm{~mL}$ of ATCC trace mineral supplement, $10 \mathrm{~mL}$ of ATCC vitamin supplement, $2 \mathrm{~mL}$ of a ferric quinate solution, $0.45 \mathrm{~mL}$ of $0.1 \%$ resazurin, $0.68 \mathrm{~g}$ of $\mathrm{KH}_{2} \mathrm{PO}_{4}$, $0.12 \mathrm{~g}$ of $\mathrm{NaNO}_{3}, 0.035 \mathrm{~g}$ of ascorbic acid, $0.37 \mathrm{~g}$ of tartaric acid, $0.37 \mathrm{~g}$ of succinic acid and $0.05 \mathrm{~g}$ of sodium acetate. The ATCC vitamin supplement solution (ATCC MD-VS) is prepared by adding to $1 \mathrm{~L}$ of distilled water $2 \mathrm{mg}$ of folic acid, $10 \mathrm{mg}$ of pyridoxine hydrochloride, $5 \mathrm{mg}$ of riboflavin, $2 \mathrm{mg}$ of biotin, $5 \mathrm{mg}$ of thiamine, $5 \mathrm{mg}$ of nicotinic acid, $5 \mathrm{mg}$ of pantothenic acid, $0.1 \mathrm{mg}$ of vitamin B12, $5 \mathrm{mg}$ of p-aminobenzoic acid, $5 \mathrm{mg}$ of thioctic acid and $900 \mathrm{mg}$ of monopotassium phosphate. The solution of mineral supplement (ATCC MD-TMS) is prepared by adding to $1 \mathrm{~L}$ of distilled water $0.5 \mathrm{~g}$ of EDTA, 3 $\mathrm{g}$ of $\mathrm{MgSO}_{4} .7 \mathrm{H}_{2} \mathrm{O}, 0.5 \mathrm{~g}$ of $\mathrm{MnSO}_{4} \cdot \mathrm{H}_{2} \mathrm{O}, 1 \mathrm{~g}$ of $\mathrm{NaCl}, 0.1 \mathrm{~g}$ of $\mathrm{FeSO}_{4} .7 \mathrm{H}_{2} \mathrm{O}, 0.1 \mathrm{~g}$ of $\mathrm{Co}\left(\mathrm{NO}_{3}\right)_{2} .6 \mathrm{H}_{2} \mathrm{O}$, $0.1 \mathrm{~g}$ of $\mathrm{CaCl}_{2}$ (anhydrous), $0.1 \mathrm{~g}$ of $\mathrm{ZnSO}_{4} .7 \mathrm{H}_{2} \mathrm{O}, 0.01 \mathrm{~g}$ of $\mathrm{Na}_{2} \mathrm{WO}_{4} .2 \mathrm{H}_{2} \mathrm{O}$ and $0.02 \mathrm{~g}$ of $\mathrm{NiCl}_{2} .6 \mathrm{H}_{2} \mathrm{O}$. The ferric quinate solution is prepared by adding to $100 \mathrm{~mL}$ of distilled water $0.27 \mathrm{~g}$ of $\mathrm{FeCl}_{3}$ and $0.19 \mathrm{~g}$ of quinic acid. After having added the chemicals indicated above, the $\mathrm{pH}$ of the growth media is adjusted to 6.75 using a $1 \mathrm{M} \mathrm{NaOH}$ solution. The growth media is then autoclaved at $121{ }^{\circ} \mathrm{C}$ for $15 \mathrm{~min}$. The bacteria provided by the ATCC are warmed up to room temperature and introduced in the three different growth media. The bacteria are kept at room temperature for one week until a change in the coloration of the growth medium is observed (from pink to white). 
Three different types of samples are prepared from intact whole cells of M. magneticum. Cells are harvested at stationary phase and by centrifugation at $8000 \mathrm{rpm}$ for 15 minutes. The supernatant (spent growth medium) is discarded and cells are resuspended in $3 \mathrm{~mL}$ of deionized water. For suspensions of whole intact cells, this sample is not treated further. To extract the chains of magnetosomes, $1 \mathrm{ml}$ of the cell suspension is recentrifuged and resuspended in a $10 \mathrm{mM}$ Tris. $\mathrm{HCl}$ buffer $(\mathrm{pH} \sim 7.4)$ and then sonicated for $60 \mathrm{~min}$. at $30 \mathrm{~W}$ to lyse releasing the chains of magnetosomes. After sonication, the suspension of extracted chains of magnetosomes is placed next to a strong magnet and the supernate containing cells debris and organic material is removed. The magnetosome chains are washed 10 times in this way and are finally resuspended in dionized water. Individual magnetosomes (not in chains) are obtained by heating the suspension of magnetosome chains for five hours at $90{ }^{0} \mathrm{C}$ in the presence of 1 $\%$ sodium dodecyl sulfate (SDS) in dionized water to disrupt the magnetosome membranes. Individual magnetosomes are washed as described for magnetosome chains and resuspended in dionized water.

\section{IV.2 Characterization of the samples:}

Samples are examined using a JEOL model JEM 1011 transmission electron microscope (JEOL Ltd, Tokyo) operating at $100 \mathrm{kV}$. Five $\mu$ l of a solution containing $210^{-4} \%$ in weight of magnetosomes are deposited on a carbon-coated copper grid and the grids are allowed to dry before examination. The same relative quantity of magnetosomes are used to prepare all samples, thus aggregation in a particular sample does not arise from a difference in the concentration of the magnetosomes.

Magnetic measurements are carried out using a vibrating sample magnetometer (VSM, Quantum design, San Diego). For magnetic measurements, $25 \mu \mathrm{l}$ of a liquid suspension of magnetotactic bacterial cells, extracted chains of magnetosomes or extracted individual magnetosomes containing 2 $10^{-3} \%$ in weight of magnetosomes, are deposited on top of a silica substrate. The samples are then positioned inside a capsule made of hard gelatin in a direction parallel to that of the magnetic field. 
Three types of magnetic measurements are performed, those of the saturating isothermal remanent magnetization (SIRM) and major or minor hysteresis loops. The SIRM measurements are used to determine the composition of the magnetosomes following a method similar to that previously described (15) and show that the magnetosomes have been almost completely oxidized in maghemite. This result is expected since we don't use fresh suspensions of magnetotactic bacteria and magnetosomes are known to oxidize in maghemite over time (24). The fact that the magnetosomes are made of maghemite instead of magnetite does not change the conclusions drawn in this paper since maghemite and magnetite have very similar magnetic properties at room temperature (15). Major hysteresis loop measurements are carried out at $300 \mathrm{~K}$ in order to determine the amount of maghemite contained within sample. The latter is determined by dividing the saturating magnetization of the samples by the saturating magnetization of maghemite. For nanoparticles as large as the magnetosomes, the saturating magnetization is that of the bulk material (in this case bulk maghemite) (ref). Finally, measurements of minor hysteresis loops are also carried out by recording the magnetization of the samples as a function of a continuous magnetic field, which is applied between $\mathrm{H}_{0}$ and $\mathrm{H}_{0}$ where $\mathrm{H}_{0}$ is $23 \mathrm{mT}, 36 \mathrm{mT}, 66 \mathrm{mT}$ or $88 \mathrm{mT}$.

\section{IV.3 Heating experiments:}

These experiments are carried out with the whole bacteria, extracted chains of magnetosomes and extracted individual magnetosomes either suspended in ultrapure water (18,6 M $\Omega$ ) or in aqueous agarose gel ( $2 \%$ by weight). The concentration of maghemite is $457 \mu \mathrm{g} \mathrm{mL}^{-1}$ for the liquid suspension containing the whole cells, $435 \mu \mathrm{g} \mathrm{mL} \mathrm{m}^{-1}$ for that containing the extracted chains of magnetosomes and

$380 \mu \mathrm{g} \mathrm{mL}^{-1}$ for that containing the extracted individual magnetosomes. $250 \mu 1$ of each of these three suspensions are poured inside polypropylene tubes and positioned at the center of a coil producing an oscillating magnetic field of frequency $108 \mathrm{kHz}$, the field amplitude being fixed at $23 \mathrm{mT}, 36 \mathrm{mT}, 66$ 
$\mathrm{mT}$ or $88 \mathrm{mT}$. In order to generate the alternating current, the coil is connected to a generator (Celes inductor C97104) and the temperature is measured using an optical fiber probe (Luxtron STF-2, BFi OPTiLAS SAS).

\section{Figures legends.}

Figure 1. Magnetic properties of intact cells of the magnetotactic bacterium Magnetospirillum magneticum strain AMB-1 containing chains of magnetosomes. (a) Transmission electron micrograph (TEM) of two cells of Magnetospirillum magneticum strain AMB-1 containing chains of magnetosomes; (b) Variation of the temperature of a suspension of intact magnetotactic bacterial cells as a function of time when the suspension is subjected to an oscillating magnetic field of frequency $108 \mathrm{kHz}$ and magnetic field amplitude of $23 \mathrm{mT}$. The dark and red lines correspond to the suspension of cells in water (sol) and in a $2 \%$ agarose gel (gel), respectively. $\Delta \mathrm{T} / \delta \mathrm{t}$ represents the slopes of the variation of the temperature with time measured at $22{ }^{0} \mathrm{C}$; (c) Same as in (b) for a magnetic field amplitude of $88 \mathrm{mT}$; (d) Minor hysteresis loops of the whole bacteria measured at $23 \mathrm{mT}$ (squares) or $88 \mathrm{mT}$ (line). (e) Surface absorption rate (SAR) of a suspension of magnetotactic bacteria contained either in water, (up triangle), or in a gel, (square), as a function of magnetic field amplitude. The hysteresis losses measured from the area of the minor hysteresis loops of a suspension of magnetotactic bacteria contained in a gel, (circle). (f): Plots in column bars of the SAR of the intact cells measured at $23 \mathrm{mT}$ and $88 \mathrm{mT}$. The blue box represents the contribution due to the hysteresis losses. 
Figure 2. Properties of the extracted chains of magnetosomes from cells of Magnetospirillum magneticum strain AMB-1. (a): TEM of extracted chains of magnetosomes; (b) Increase in temperature of the extracted chains of magnetosomes as a function of time in the presence of an oscillating magnetic field of frequency $108 \mathrm{kHz}$ and field amplitude $23 \mathrm{mT}$. The dark and red lines indicate the heating rate of to the extracted chains of magnetosomes suspended in water (sol) or in a 2 $\%$ agarose gel (gel) respectively. $\Delta \mathrm{T} / \delta \mathrm{t}$ represents the slopes of the variation of the temperature with time measured at $22^{\circ} \mathrm{C}$; (c) Same as in (b) for a magnetic field amplitude of $88 \mathrm{mT}$; (d) Minor hysteresis loops of extracted chains of magnetosomes at $23 \mathrm{mT}$ (square) and $88 \mathrm{mT}$ (line). (e) SAR measured from the slope at $22{ }^{0} \mathrm{C}$ of the heating rate of the extracted chains of magnetosomes suspended in water, (up triangle), or in a gel, (square), as a function of the magnetic field amplitude. Hysteresis losses measured from the area of the minor hysteresis loops of a suspension of extracted chains of magnetosomes contained in a gel, (circle). (f): Plots in column bars of the SAR of the extracted chains of magnetosomes measured at $23 \mathrm{mT}$ and $88 \mathrm{mT}$. Blue and green boxes represent the contributions arising from the hysteresis losses and rotation of the chains of magnetosomes respectively.

Figure 3. Properties of extracted individual magnetosomes from cells of Magnetospirillumm magneticum strain AMB-1. (a): TEM of an assembly of extracted individual magnetosomes; (b) Increase in temperature of the extracted individual magnetosomes as a function of time when an oscillating magnetic field of frequency $108 \mathrm{kHz}$ and amplitude $23 \mathrm{mT}$ is applied. The dark and red lines indicate the variations in temperature of the individual magnetosomes suspended in water (sol) or in a $2 \%$ agarose gel (gel), respectively. $\Delta \mathrm{T} / \delta \mathrm{t}$ represents the slopes of the variation of the temperature with time measured at $22{ }^{0} \mathrm{C}$; (c) Same as in (b) for magnetic field amplitude of $88 \mathrm{mT}$. (d): Minor 
hysteresis loops of the individual magnetosomes measured at $23 \mathrm{mT}$ (square) and $88 \mathrm{mT}$ (line); (e) SAR measured from the slope at $22{ }^{0} \mathrm{C}$ of the heating rate of the individual magnetosomes contained either in water, (up triangle), or in a gel, (square), as a function of the magnetic field amplitude. Hysteresis losses measured from the area of the minor hysteresis loops of the individual magnetosomes contained in a gel, (circle). (f): Plots in column bars of the SAR of the individual magnetosomes measured at $23 \mathrm{mT}$ and $88 \mathrm{mT}$. Blue and green boxes represent the contributions arising from the hysteresis losses and rotation of the chains of magnetosomes respectively.

Acknowledgment: We would like to thank the French biotech company Nanobacterie, SARL, for participating in this study. 


\section{References:}

1. For a comprehensive review on magnetotactic bacteria: Bazylinski, D., A.; Frankel, R., B., Nat. Rev. Microbiol. 2, 217-230 (2004).

2. Arakaki, A.; Nakazawa, H.; Nemoto, M.; Mori, T.; Matsunaga, T.; J. R. Soc. Interface 5, 977999 (2005).

3. Duguet, E.; Mornet S.; Vasseur, S.; Devoisselle, J.M.; Nanomed. 1, 157-168 (2006).

4. Ito, A.; Honda, H.; Kobayahi, T.; Cancer Immunol. Immun. 55, 320-328 (2006).

5. Ciofani, G.; Riggio, C.; Raffa, V.; Menciassi, A.; Cuschieri, A.; Med. Hypotheses 73, 80-82 (2009).

6. Dutz, S.; Hergt, R.; Mürbe, J.; Müller, R.; Zeisberger, M.; Andrä, W.; Tőpfer, J.; Bellemann, M., E., J. Magn. Magn. Mater. 308, 305-312 (2007).

7. Bae, Y.; Buresh, R., A.; Williamson, T., P.; Chen, T-H. H., Furgeson, D. Y.; J. Controlled Release 122, 16-23 (2007).

8. Hilger, I.; Wilfried, A.; Hergt, R.; Hiergeist, R.; Schubert, H.; Kaiser, A., K.; Radiology 218, 570-575 (2001).

9. See for example: Oberdörster, G.; Oberdörster, E.; Oberdörster, J.; Environ. Health Persp. 113, 823-839 (2005).

10. Habib, A., H.; Ondeck, C., L.; Chaudhary, P.; Bockstaller, M., R.; McHenry, M. E.; J. Appl. Phys. 103, 07A307-1-07A307-3 (2008). 
11. Hergt, R.; Dutz, S.; Müller, R.; Zeisberger, M.; J. Phys. Condens. Matter 18, S2919-S2934 (2006).

12. Hergt, R.; Hiergeist, R.; Zeisberger, M.; Schüler, D.; Heyen, U.; Higler, I.; Kaiser, W. A.; $J$. Magn. Magn. Mater. 293, 80-86 (2005).

13. Timko, M.; Dzarova, A.; Kovac, J.; Skumiel, A.; Jozefczak, A.; Hornowski, T.; Gojzewsi, H.; Zavisova, V.; Koneracka, M.; Sprincova, A.; Stbak, O.; Kopcansky, P.; Tomasovicova, N.; J. Mag. Mag. Mat. 321, 1521-1524 (2009).

14. Alphandery, E.; Ding, Y.; Ngo, A. T.; Wang, Z. L.; Wu, L. F.; Pileni, M. P.; ACS Nano 3, $1539-1547$ (2009).

15. Alphandéry, E.; Ngo, A. T.; Lefèvre, C.; Lisiecki, I.; Wu, L., F.; Pileni, M. P.; J. Phys. Chem. C 112, 12304-12309 (2008).

16. Hergt, R.; Andrä, W.; d'Ambly, C. G.; Higler, I.; Kaiser, W. A.; Richter, U.; Schmidt, H-G.; IEEE Trans. Mag. 34, 3745-3754 (1998).

17. In (2), we have assumed that the Brownian relaxation time, $\tau_{\mathrm{b}}$, is much smaller than the Néel relaxation time $\tau_{\mathrm{n}}$, where $\tau_{\mathrm{b}}=3 \eta \mathrm{V} / \mathrm{K}_{\mathrm{b}} \mathrm{T}$ and $\tau_{\mathrm{n}}=\tau_{0} \exp \left(\mathrm{E}_{\mathrm{a}} / \mathrm{K}_{\mathrm{b}} \mathrm{T}\right)$. For the different samples, $\tau_{\mathrm{b}}$ lies between $2.510^{-5} \mathrm{sec}$. and $10 \mathrm{sec}$ (See ref. 18). Given that $\tau_{0} \sim 10^{-9} \mathrm{sec}$ and the ration between the anisotropy energy of a chain of magnetosomes and the thermal energy, $\mathrm{E}_{\mathrm{a}} / \mathrm{K}_{\mathrm{b}} \mathrm{T} \sim$ 480 (See ref. 14), we find that $\tau_{\mathrm{n}} \sim 3.10^{38}$ sec. and hence $\tau_{\mathrm{b}} / \tau_{\mathrm{n}} \sim<<1$. This justifies the use of (2) to measure the SAR.

18. The Brownian relaxation times are estimated using the formula $\tau_{b}=3 \eta V_{h} / K_{b} T$, where $V_{h}$ is the hydrodynamic radius. For the whole magnetotactic bacteria, we consider that $V_{h}=4 / 3 \pi r^{3}$, where $r$ is half the typical length of a bacterium $(1.5 \mu \mathrm{m})$. For the chains of magnetosomes and individual magnetosomes, the hydrodynamic radius are simply estimated as being either the 
volume of a typical chain of magnetosomes $\left(\mathrm{V}_{\mathrm{h}} \sim 2010^{-23} \mathrm{~m}^{3}\right)$ or of a single magnetosome $\left(\mathrm{V}_{\mathrm{h}}\right.$ $\sim 3.310^{-23} \mathrm{~m}^{3}$ ). Using $\eta=10^{-3}$ Pa.sec and $\mathrm{T} \sim 295 \mathrm{~K}$, this yields $\tau_{\mathrm{b}} \sim 10$ sec. for a whole bacterium, $\tau_{\mathrm{b}} \sim 1.510^{-4} \mathrm{sec}$. for an extracted chain of magnetosomes and $\tau_{\mathrm{b}} \sim 2.510^{-5} \mathrm{sec}$. for an individual magnetosome.

19. Kobayashi, A.; Kirschvink, J., L.; Nash, C., Z.; Kopp, R., E.; Sauer, D., A.; Bertani, L. E.; Voorhout, W., F.; Taguchi, T.; Eearth. Planet. Sc. Lett. 245, 538-5550 (2006).

20. Ma, M.; Wu, Y.; Zhou, J.; Sun, Y.; Zhang, Y.; Gu, N. J.Magn.Magn.Mater. 268, 33-39 (2004).

21. Jordan, A.; Rheinländer, T.; Waldöfner, N.; Scholz, R. J.Nano.Res. 5, 597-600 (2003).

22. Brusentsov, N. A.; Gogosov, V. V.; Brusentsova, T. N.; Sergeev, A. V.; Jurchenko, N. Y.; Kuznetsov, A. A.; Kuznetsov, O. A.; Shumakov, L. I. J.Magn.Magn.Mater. 225, 113-117 (2001).

23. Chan, D. C. F.; Kirpotin, D. B.; Bunn, P. A. In Scientific and clinical applications of magnetic carriers; Plenum Press ed.; Edited by Häfeli, U.; Schütt, W.; Teller, J.; Zborowski, M., New York, 607-618 (1997).

24. Chen, T.; Xu, H.; Xie, X.; Chen, J.; Ji, J.; Lu, H.; Earth Planet. Sci. Lett. 240, 790-802 (2005). 


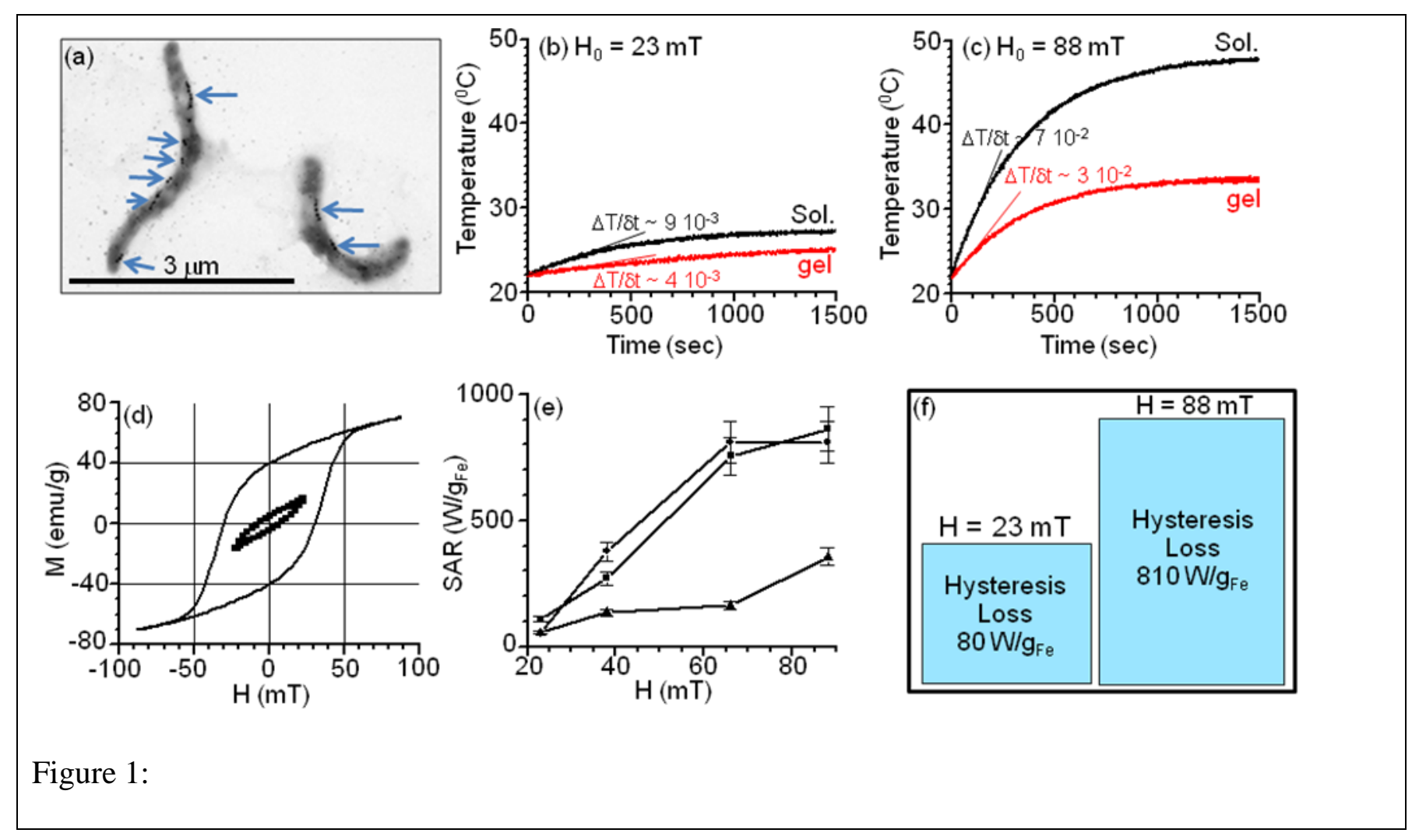



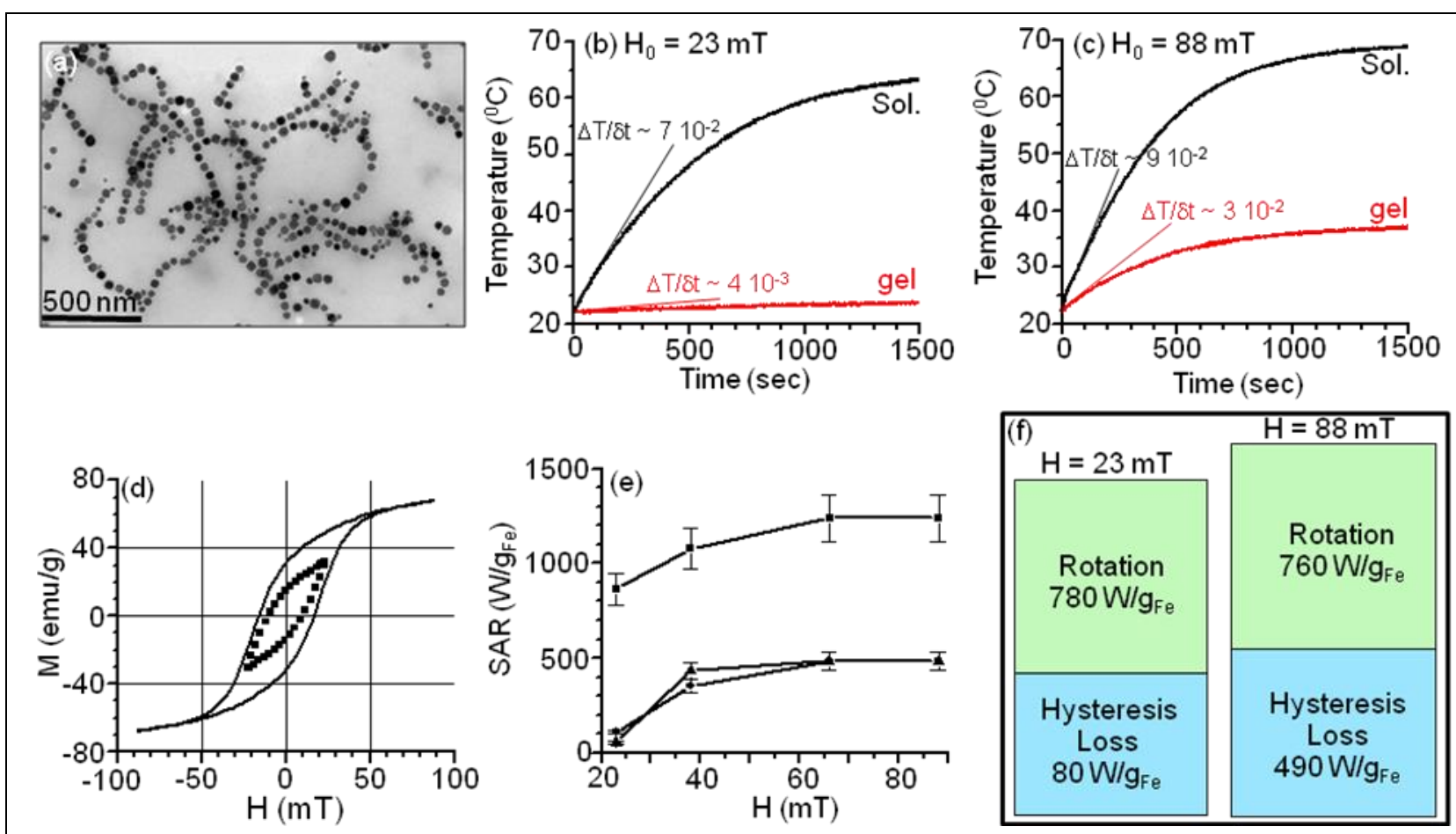

Figure 2. 


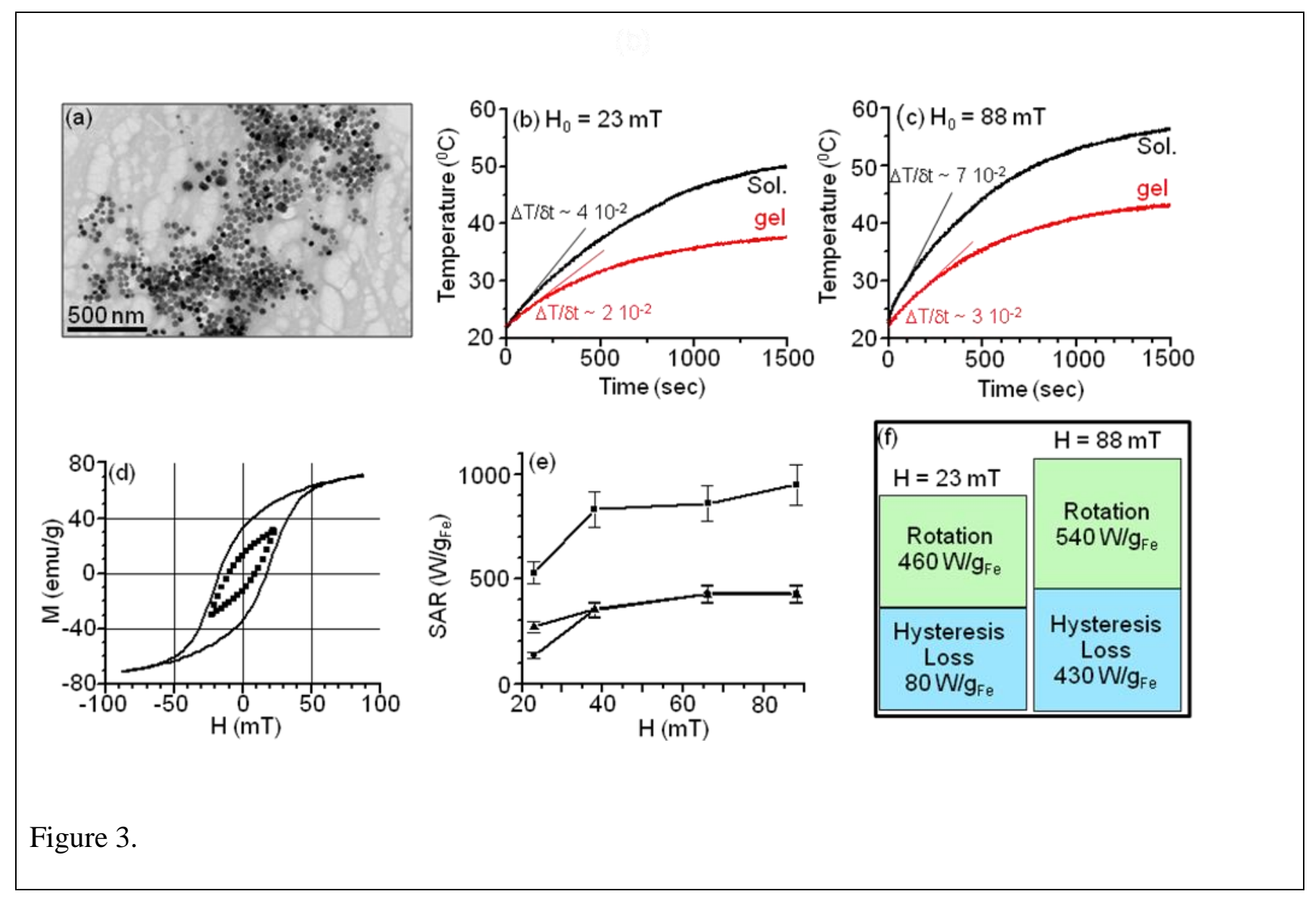

